\title{
BADANIA ARCHEOLOGICZNE PROWADZONE PRZEZ INSTYTUT HISTORII FILII UNIWERSYTETU WARSZAWSKIEGO W BIAEYMSTOKU W 1996 ROKU
}

Badania archeologiczne prowadzone przez Instytut Historii Filii Uniwersytetu Warszawskiego w Białymstoku koncentrują się od 1993 roku na obszarze południowej części Krainy Wielkich Jezior Mazurskich. Podjęto je w ramach realizowanych przez Instytut studiów nad kulturowym i naturalnym krajobrazem Mazur w starożytności i średniowieczu, jak też na zlecenie Konserwatora Zabytków Archeologicznych w Suwałkach. Badania finansowane były przez Instytut Historii Filii UW w Białymstoku, Muzeum Okręgowe w Suwałkach, Konserwatora Zabytków Archeologicznych w Suwałkach i Urząd Gminy Miłki. Wszystkimi badaniami kierowali mgr mgr Małgorzata Karczewska i Maciej Karczewski.

W dniach 17-18 kwietnia 1996 r. przeprowadzone zostały badania planigraficzne na wielokulturowej osadzie w Marcinowej Woli Kolonii, st. 12. Zajmuje ona rozległe wyniesienie o ekspozycji okrężnej, znajdujące się na północnym brzegu torfowiska Nietlice, na południowy zachód od wsi. W trakcie wcześniejszych badań powierzchniowych prowadzonych w ramach „badań torfowych” (1984 r.), weryfikacyjnych (1991 r.) i Archeologicznego Zdjęcia Polski (1993 r.) odkryto tu relikty rozległych osad, które na podstawie zebranego $\mathrm{z}$ powierzchni materiału datowano wstępnie na czasy od neolitu po wczesne średniowiecze, przy czym większość zabytków pochodziła $z$ okresu wpływów rzymskich i okresu wędrówek ludów ${ }^{1}$. Kolejne wizytacje stanowiska wykazały szybki postęp degradacji wyniesienia w wyniku erozji stokowej wywołanej orką. Znaczna ilość materiału zabytkowego zalegającego na powierzchni stanowiska, wskazująca, że znajduje się ono w fazie intensywnego niszczenia skłaniała do podjęcia tu natychmiastowych, ratowniczych badań archeologicznych. Przeprowadzono je z zastosowaniem geodezy jnych metod rejestracji danych, co pozwoliło na zarejestrowanie rozrzutu materiału zabytkowego na obszarze o powierzchni przekraczającej 6 ha w ciągu zaledwie dwóch $\mathrm{dni}^{2}$.

Na powierzchni stanowiska zarejestrowano łącznie 704 punkty, z których zebrano ok. 800 zabytków. Dominowały wśród nich fragmenty ceramiki, obok których natrafiono też na bryłki polepy, fragmenty kości zwierzęcych, pojedyncze zabytki krzemienne, rozcieracze kamienne i kamień żarnowy od żaren nieckowatych. Największe 
nasycenie zabytkami wystąpiło na kulminacji wyniesienia oraz na jego południowym i wschodnim stoku. Duże fragmenty ceramiki z dobrze zachowanymi przełomami grupowały się w partii wierzchołkowej wyniesienia, gdzie odkryto też wychodnię warstwy kulturowej. Mogą one świadczyć o niszczeniu znajdujących się w tej części stanowiska obiektów przestrzennych. Mniejsze fragmenty ceramiki o często zatartych przełomach i zdartych powierzchniach wystąpiły w dolnych partiach wyniesienia. Wstępne datowanie materiału zabytkowego zebranego w trakcie badań planigraficznych potwierdziło ustaloną wcześniej chronologię stanowiska.

Równocześnie z badaniami planigraficznymi, w dniach 16-20 kwietnia, na zlecenie Konserwatora Zabytków Archeologicznych w Suwałkach przeprowadzone zostały poszukiwania archeologiczne w ramach Archeologicznego Zdjęcia Polski na obszarze $22-74^{3}$.

Obszar objęty prospekcją terenową znajduje się w południowo-wschodniej części Krainy Wielkich Jezior Mazurskich i obejmuje dwie strefy krajobrazowe: południowo-wschodnią część torfowiska Nietlice i otaczający je od południa i wschodu obszar moreny pagórkowatej z jeziorami rynnowymi: Buwełno, Tyrkło, Ublik Wielki i Ublik Mały. W wyniku badań terenowych i poprzedzającej je kwerendy archiwalnej przeprowadzonej w Instytucie Archeologii i Etnologii PAN w Warszawie oraz Działach Archeologii Muzeum Warmii i Mazur w Olsztynie i Muzeum Okręgowym w Suwałkach, odkryte zostały łącznie 24 stanowiska archeologiczne. Zawierały one relikty osadnictwa $\mathrm{z}$ epoki kamienia (9 stanowisk), epoki brązu (3 stanowiska), wczesnej epoki żelaza (1 stanowisko), okresu wpływów rzymskich (6 stanowisk), okresu wędrówek ludów (1 stanowisko), średniowiecza (18 stanowisk) i okresu nowożytnego (6 stanowisk). Większość odkrytych stanowisk zawierała ślady osadnictwa z kilku okresów chronologicznych. Na czterech z nich odnaleziono też zabytki, których chronologię określono ogólnie jako pradziejową.

Spośród odkrytych stanowisk na szczególną uwagę zasługuje neolityczna osada kultury Narva w Cierzpiętach, stan. 10. Jest ona jednym z pierwszych tego typu stanowisk odkrytych w południowej części Mazur. W jej pobliżu - w obrębie południowo-wschodniej strefy Bagien Nietlickich - należy też lokalizować wzmiankowane w literaturze stanowiska kultury amfor kulistych i kultury ceramiki sznurowej ${ }^{4}$.

W lipcu, w trakcie badań wykopaliskowych na cmentarzysku kultury bogaczewskiej w Paprotkach Kolonii, st. 1, prowadzonych przez Dział Archeologii Muzeum Okręgowego w Suwałkach i Dział Archeologii Bałtów Państwowego Muzeum Archeologicznego w Warszawie ${ }^{5}$, przeprowadzony został nadzór archeologiczny w obrębie wykopu budowlanego pod odbudowywaną szkołę w Rydzewie. W wyniku nadzoru zostało odkryte nowe stanowisko związane $\mathrm{z}$ początkami wczesnonowożytnej historii tej miejscowości - Rydzewo, stan. $69^{6}$.

Wykop pod fundamenty szkoły znajdował się na wschód od kościoła rydzewskiego, na gruntach szkolnych graniczących z gruntami kościelnymi. W dniu 25.07.1996 r. w trakcie sprawdzania profili wykopu pod fundamenty natrafiono na fragmenty ceramiki i kafla wczesnonowożytnego (5 fragmentów brzuśców, 2 frag- 
menty wylewów i 1 fragment kafla - chronologia XVII-XIX w.). Odnaleziono je w warstwie przemieszanej, zniszczonej przez now.ożytną zabudowę. Ponadto, we wschodniej części południowego profilu wykopu, na głębokości ok. $55 \mathrm{~cm}$ poniżej współczesnej powierzchni gruntu natrafiono na warstwę polepy. Bezpośrednio pod tą warstwą i w jej obrębie odnalezionych zostało dwanaście fragmentów ceramiki i dwa fragmenty kafli (chronologia - 1 fragment wylewu i 4 fragmenty brzuśca późne średniowiecze/początek ery nowożytnej; 6 fragmentów z brzuśców i 1 fragment dna oraz 2 fragmenty kafli - XVI-XVII w.). Powyżej warstwy polepy natrafiono na jeden fragment ceramiki średniowiecznej i cztery fragmenty ceramiki nowożytnej (1 fragment - średniowiecze; 3 fragmenty z brzuśców i 1 fragment wylewu z zielonkawożółtą polewą - okres nowożytny - XVIII - pocz. XX w.).

Największy zakres spośród badań archeologicznych prowadzonych w 1996 r. przez Instytut Historii Filii UW w Białymstoku miały badania wykopaliskowe na stanowisku 41 w Paprotkach Kolonii, prowadzone w dniach 15.07-11.08.1996 r. przy współpracy z Działem Archeologii Muzeum Okręgowego w Suwałkach. Stanowisko to kryje m.in. relikty osiedla kultury bogaczewskiej, której ludność składała swych zmarłych na wymienionym wyżej cmentarzysku w Paprotkach Kolonii, st. 1. Rok 1996 był trzecim z kolei sezonem badań wykopaliskowych prowadzonych na tej osadzie $^{7}$.

W wyniku współpracy nawiązanej przez Dział Archeologii Muzeum Okręgowego w Suwałkach i Instytut Historii z Instytutem Biologii Filii UW w Białymstoku w wykopaliskach wzięły udział dr dr Mirosława Kupryjanowicz i Ewa Pirożnikow. Umożliwiło to przeprowadzenie badań makroszczątków roślinnych i zwierzęcych zawartych w próbach warstwy kulturowej i wypełnisk odkrytych obiektów, a także wykonanie serii wierceń w torfowisku Nietlice. Celem wierceń było uchwycenie granicy zerowej złoża torfu oraz wstępne rozpoznania przydatności osadów torfowiska do badań palinologicznych. Ich wyniki potwierdziły przydatność złoża do analizy pyłkowej, a granica zerowa złoża torfu została uchwycona na poziomie pokrywajacym się w przybliżeniu z przebiegiem poziomicy o wartości 120 m n.p.m.

Badaniami wykopaliskowymi objęto $249,2 \mathrm{~m} \mathrm{kw}$. powierzchni stanowiska, z czego całkowicie wyeksplorowano $74 \mathrm{~m} \mathrm{kw}$. Eksplorację prowadzono w obrębie czterech wykopów -- nr VI-IX (utrzymano ciągłość numeracji wykopów z poprzednich sezonów badań). Trzy z nich (VI, VII i VIII) zlokalizowano w centralnej części cypla zajmowanego przez stanowisko, w bezpośrednim sąsiedztwie wykopu V z 1995 r. Wykop IX wytyczony został w północno-wschodniej partii cypla, na północ od wykopu IV z 1995 r.

Ze względu na wyjątkowo duże nagromadzenie nowo odkrytych obiektów, eksploracja prowadzona była jedynie w trzech wykopach: VI, VII i IX. W ich obrębie odsłonięto 32 obiekty przestrzenne, datowane na wczesną epokę żelaza, okres wpływów rzymskich i okres wędrówek ludów. Trzydzieści z nich stanowiły jamy gospodarcze o zróżnicowanej funkcji (obiekty: 13, 14, 25, 26 w wykopie VI i obiekty: 10, 15-24, 27-41 w wykopie VII), natomiast jeden - obiekt 5 , była to rozległa, płytka 
jama o zarysie zbliżonym do prostokąta i niemożliwej do jednoznacznego ustalenia funkcji.

Całkowicie przebadano wypełniska obiektów: 10-16, 17, 21, 25, 26, 32 i 34, natomiast obiekty: 18-24, 27-31,33, 35-41 zostały zadokumentowane na poziomie stropów wypełnisk i, po zabezpieczeniu, pozostawione do przyszłego sezonu wykopaliskowego. Spośród badanych w 1996 roku obiektów na szczególną uwagę zasługuje obiekt 5 oraz obiekty $10,13,32$ i 34 .

Obiekt 5 odkryty został już w 1995 r. w obrębie północnej części wykopu IV. Zinterpretowano go wówczas jako „rozległe, wybrukowane otoczakami palenisko”. Zbadanie w 1996 r. dalszej części jego wypełniska pozwoliło na weryfikację tej tezy. Obiekt 5 tworzyła warstwa ciemnoszarobrunatnego piasku, w obrębie której odnalezione zostały liczne fragmenty naczyń glinianych i kości zwierzęcych, oraz duża ilość różnej wielkości kamieni, które nie tworzyły żadnych regularnych układów. Pod tą warstwą zalegała warstwa szarej gliny z licznymi węglami drzewnymi, pozbawiona materiału zabytkowego. Na wschodnim i południowo-wschodnim skraju obiektu 5 natrafiono na dwie rozległe jamy posłupowe. Osadzone w nich słupy mogły wspierać jednospadowy dach przykrywający obiekt 5 . Dach ten podniesiony był w kierunku wschodnim, zaś od zachodu opierał się bezpośrednio na powierzchni gruntu. Głębokość obiektu można zrekonstruować na podstawie miąższości warstw jego wypełniska. Wraz z warstwą szarej gliny nie przekraczała ona $65 \mathrm{~cm}$, a bez tej warstwy wynosiła ok. $30 \mathrm{~cm}$. Średnice wypełniska obiektu miały długość: 7-7,5 m i $3 \mathrm{~m}$. Wyniki badań nie pozwalają na jednoznaczne określenie, czy obiekt 5 posiadał ściany, czy też była to lekka, zadaszona konstrukcja, otwarta od północy, wschodu i południa. Nie można jednak wykluczyć, że przynajmniej w części ściany obiektu były wzniesione z kamieni, których znaczną ilość odnaleziono w jego wypełnisku.

Ceramika o prosto ściętych wylewach, odkryta w dolnej części wypełniska obiektu 5 pozwala na przypisanie go kulturze kurhanów zachodniobałtyjskich i ustalenie jego chronologii na wczesną epokę żelaza ${ }^{8}$.

Obiekty 10,13, 32 i 34 stanowiły pozostałości jam gospodarczych o różnorakim przeznaczeniu.

Obiekt 10 była to rozległa, kolista, płytka jama śmietniskowa o wymiarach: $114 \times 120 \mathrm{~cm}$ i głębokości $45 \mathrm{~cm}$. Górną część jej wypełniska tworzyła zbita warstwa polepy przemiesznej z fragmentami przepalonej ceramiki. Odnaleziono tu też fragmenty kości zwierzęcych i liczne szczątki ryb.

Obiekt 13 był z kolei reliktem jamy do gotowania i pieczenia. Jej głębokość dochodziła do $54 \mathrm{~cm}$, a średnice kolistego w zarysie wypełniska miały długość 100 i $108 \mathrm{~cm}$. W intensywnie czarnym, przesyconym węglami drzewnymi wypełnisku obiektu natrafiono na fragmenty naczyń glinianych i kości zwierzęcych oraz dużych rozmiarów kamień zbliżony kształtem do prostopadłościanu, o wyraźnie wygładzonej większej z podstaw. Kamień ten stał pierwotnie w północno-zachodniej części jamy na mniejszej z podstaw, na bruku z drobnych kamieni. Po utracie swej funkcji kamień przewrócił się i osiadł na warstwie węgla drzewnego o miąższości ok. 8-9 cm. 
Obiekty 32 i 34 stanowiły pozostałość jednej jamy zasobowej, o głębokości $80 \mathrm{~cm}$ i szerokości $122-126 \mathrm{~cm}, \mathrm{z}$ wejściem od południa. Dno jamy wyłożone było fragmentami naczyń glinianych i wylepione gliną noszącą ślady działania ognia. Po utracie pierwotnej funkcji obiekt ten stał się jamą odpadkową. W górnej części jego wypełniska odnalezione zostały trzy kamienie zarnowe od żaren nieckowatych, trzy rozcieracze i jeden kamień $z$ wygładzoną powierzchnią.

W zasypiskach wyeksplorowanych jam gospodarczych natrafiono na fragmenty ceramiki, polepy, fragmenty kości zwierzęcych i szczątki ryb. Brak precyzyjnych wyznaczników chronologicznych uniemożliwia ich dokładne datowanie. Natomiast odkryte w wypełniskach wszystkich jam fragmenty naczyń glinianych pochodzą $\mathrm{z}$ okresu wpływów rzymskich lub/i okresu wędrówek ludów, co pozwala na wiązanie tych obiektów z kulturą bogaczewską.

Wyniki przeprowadzonych dotychczas badań nad kulturowymi naturalnym krajobrazem Mazur w starożytności i średniowieczu potwierdzają istnienie na obszarze południowej części Krainy Wielkich Jezior Mazurskich, szczególnie zaś pomiędzy jeziorem Niegocin i torfowiskiem Nietlice, strefy osadniczej, zasiedlanej od epoki kamienia po początki ery nowożytnej. Ślady szczególnie intensywnego osadnictwa związane są z epoką żelaza. W jej początkach osadnictwo koncentrowało się wokół nie istniejącego dzisiaj jeziora, którego pozostałością jest w części torfowisko Nietlice z zanikającym jeziorem Wąż. Pozostałościami największych osiedli funkcjonujących tu w tym okresie są stanowiska: $41 \mathrm{w}$ Paprotkach Kolonii i $12 \mathrm{w}$ Marcinowej Woli Kolonii. W początkach średniowiecza osadnictwo przenosi się bardziej na północ - nad południowy brzeg jeziora Niegocin, w okolice dzisiejszej wsi Rydzewo. Zmiana ta mogła wiązać się ze stopniowym zarastaniem płytkiego jeziora Wąż i w związku z tym z pogorszeniem się warunków dla rozwoju osadnictwa nad jego brzegami.

Dobry stan zachowania reliktów osadnictwa oraz znaczny stopień zaawansowania badań archeologicznych, którym towarzyszą analizy paleoekologiczne pozwalają przypuszczać, że w najbliższym czasie obszar pomiędzy jeziorami Niegocin i Śniardwy stanie się jedną z najlepiej rozpoznanych pod względem archeologicznym części Mazur.

\section{Maciej Karczewski}

\section{PRZYPISY}

1. M. Karczewski, Osadnictwo pradziejowe i wczesnośredniowieczne w Krainie Wielkich Jezior Mazurskich i na Pojezierzu Ełckim. Wyniki poszukiwań archeologicznych wokót torfowiska Lajty, Nietlice, Czarnc Lqki i Gawliki Wielkie, maszynopis pracy magisterskiej w archiwum Katedry Archeologii UMCS w Lublinie. Pochodzące $\mathrm{z}$ badań AZP na obszarze 21-74 dokumentacja i materiał zabytkowy znajdują się w archiwum Konserwatora Zabytków Archeologicznych w Suwałkach. 
2. A. Bitner-Wróblewska, J. Brzozowski, J. Siemaszko, Nowe możliwości wykorzystania metody planigraficznej w badaniach archeologicznych, „Archeologia Polski”, t. XLI, z. 1-2, 1996, s. 7-38.

3. Pochodzące $z$ badań materiał zabytkowy i dokumentacja znajdują się w archiwum Konserwatora Zabytków Archeologicznych w Suwałkach.

4. W. Gaerte, Die steinzeitliche Keramik Ostpreussens, Königsberg 1927, S. 55, Taf. 155, 248; J. Heideck, Kultur- und Bergräbnisstätte bei Cziespienten, „Sitzungsberichte der Altertumsgesellschaft Prussia", Heft 21: 1889-1900, S. 293; W. La Baume, Jungsteinzeitliche Kugelamphorkultur in Ost- und Westpreussen, "Sitzungsberichte der Altertumsgesellschaft Prussia", Heft 22:1900-1904, S. 202; Katalog des Prussia-Museums zu Königsberg i. Pr., Teil I: Stein-, Bronze-, Eisenzeit I (La Tenezeit), Königsberg 1906, S. 7; E. Hollack, Erläuterungen zur vorgeschichtlichen Übersichtskarte von Ostpreussen, Glogau-Berlin 1908, S. 24; C. Engel, W. La Baume, Kulturen und Völker der frühzeit im Preussenlande, Königsberg 1937, S. 237; J. Okulicz, Pradzieje ziem pruskich od późnego paleolitu do VII w. n.e., Wrocław-Warszawa-Kraków 1973, s. 100, 104; R. Odoj, Pradzieje, [w:] Giżycko. $Z$ dziejów miasta i okolic, Olsztyn 1983, s. 53.

5. Paprotki Kolonia, st. 1, „Informator Archeologiczny. Badania 1991, 1992, 1993, 1994, 1996”, w druku. Badaniami na cmentarzysku kierują mgr mgr Anna Bitner-Wróblewska, Małgorzata Karczewska, Maciej Karczewski.

6. Dokumentacja i materiał zabytkowy znajdują się w zbiorach Działu Archeologii Muzeum Okręgowego w Suwałkach.

7. Paprotki Kolonia, st. 41, „Informator Archeologiczny. Badania 1994, 1995, 1996” (w druku); M. Karczewski, Badania nad osadnictwem plemienia Galindoi w południowej części Krainy Wielkich Jezior Mazurskich w okresie rzymskim, „Białostocczyzna” (w druku).

8. Identyczne fragmenty ceramiki zostały odkryte w trakcie podwodnych badan archeologicznych na reliktach osady kultury kurhanów zachodniobałtyjskich w Jeziorze Bocznym położonym zaledwie $6 \mathrm{~km}$ na północny zachód od osady w Paprotkach Kolonii, st. 41 - por. J. M. Łapo, W. Ossowski, Prace inwentaryzacyjne na osadzie z wczesnych okresów epoki. zelaza w Bogaczewie, stan. 2, woj. Suwałki. Metoda i wyniki, [w:] Archeologia Podwodna Jezior Niżu Polskiego. Materiały z konferencji Podwodne Archeologiczne Zdjęcie Polski Nizowych stref Pojeziernych, Wilkasy 21-22 kwietnia 1994, pod red. A. Kola, Toruń 1995, s. 43-52. 
Wyniki badań planigraficznych

na stanowisku 12 w Marcinowej Woli Kolonii

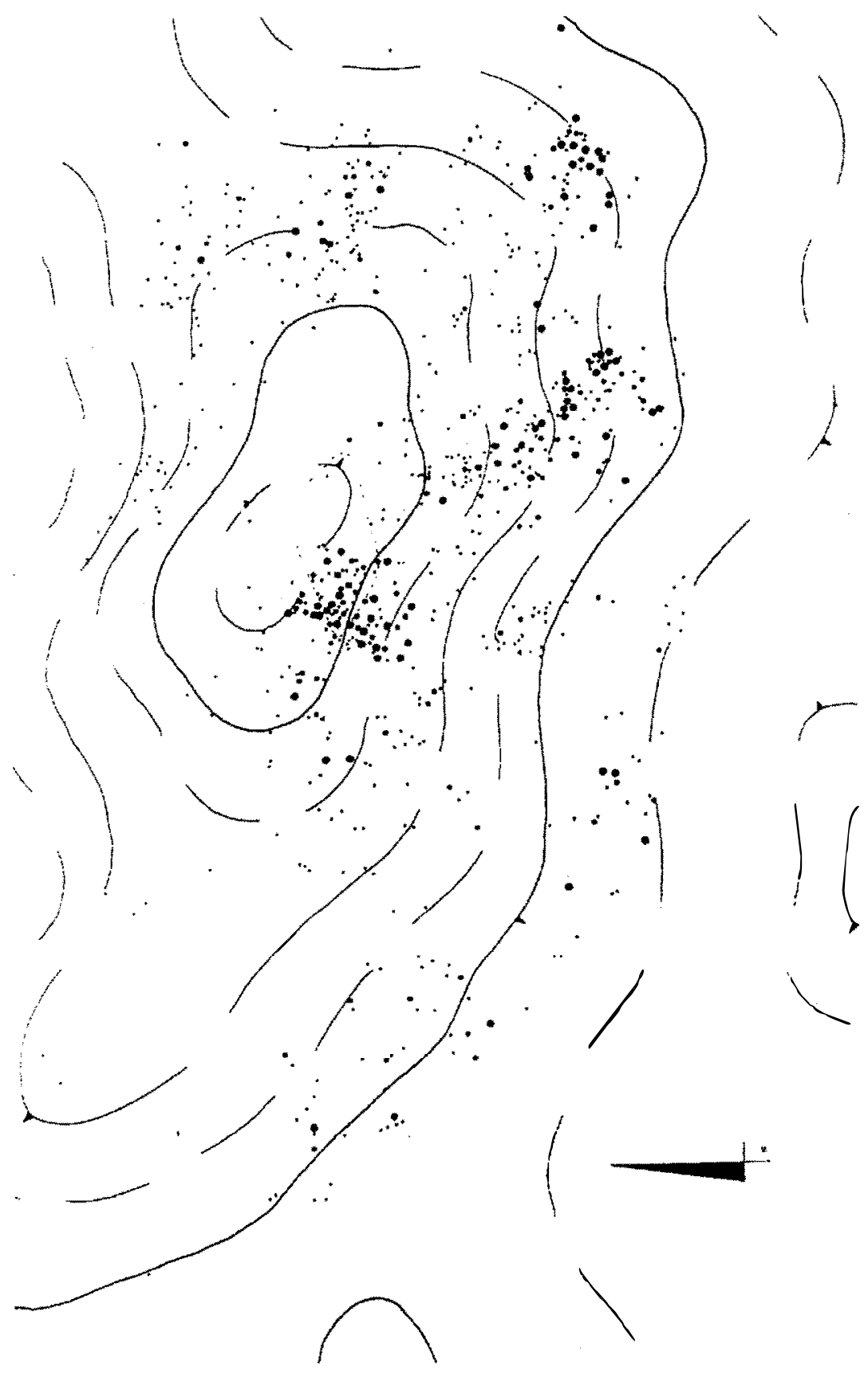


Żarna nieckowate odkryte $w$ trakcie badań planigraficznych na stanowisku 12 w Marcinowej Woli Kolonii

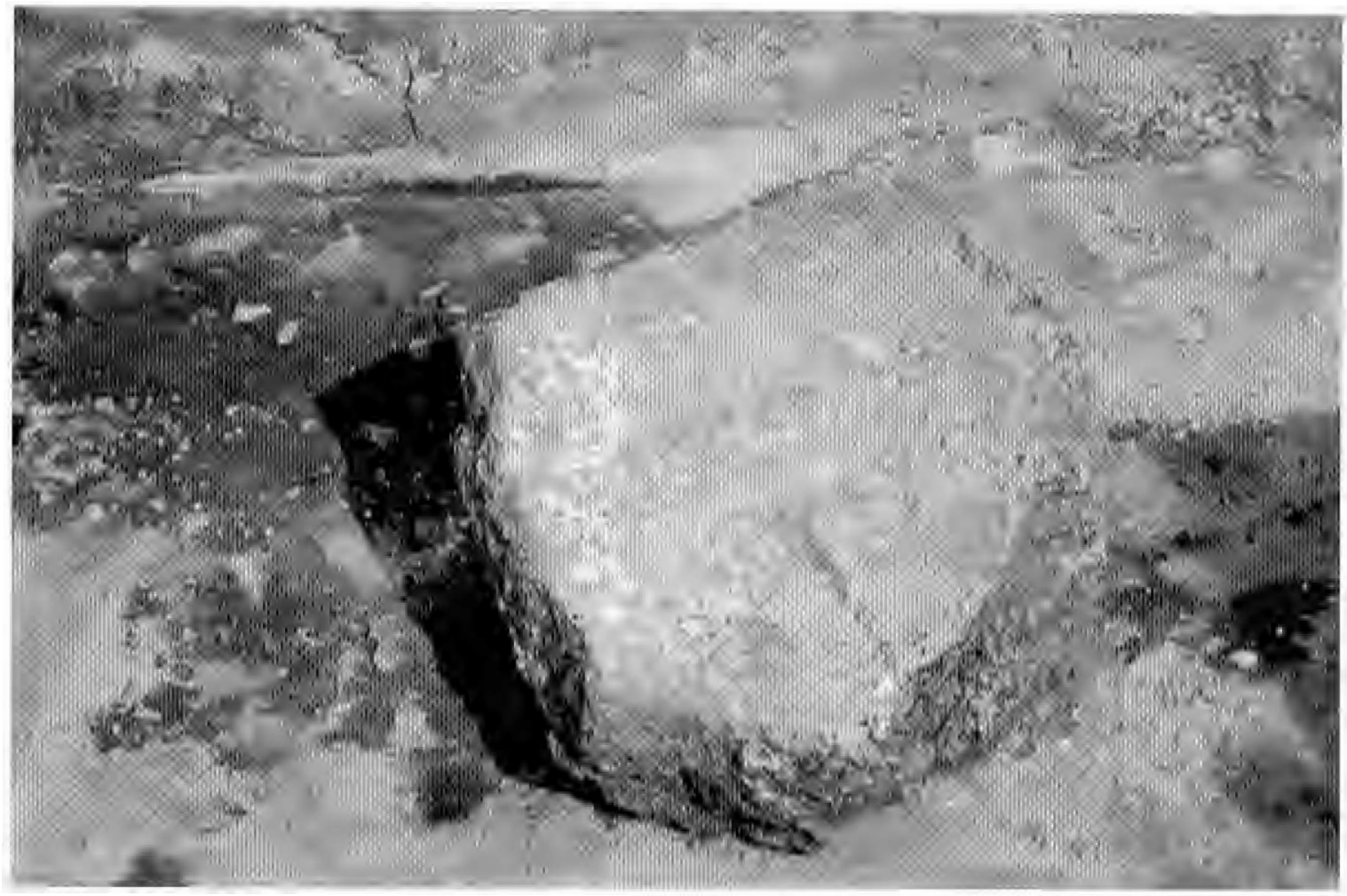


Profil z widoczną wczesnonowożytną warstwą kulturową

w obrębie wykopu budowlanego pod fundament szkoły w Rydzewie - Rydzewo, stan. 69

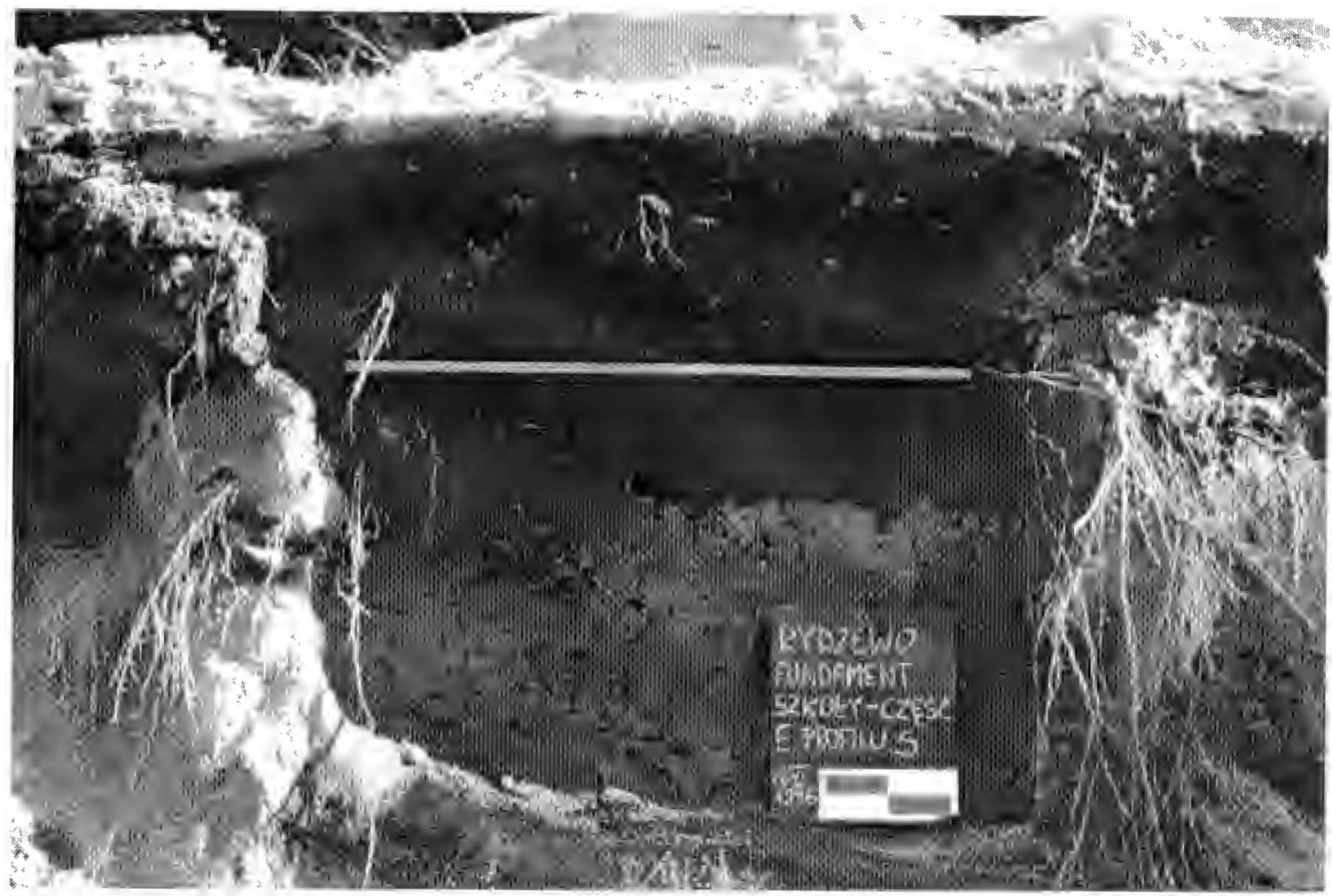




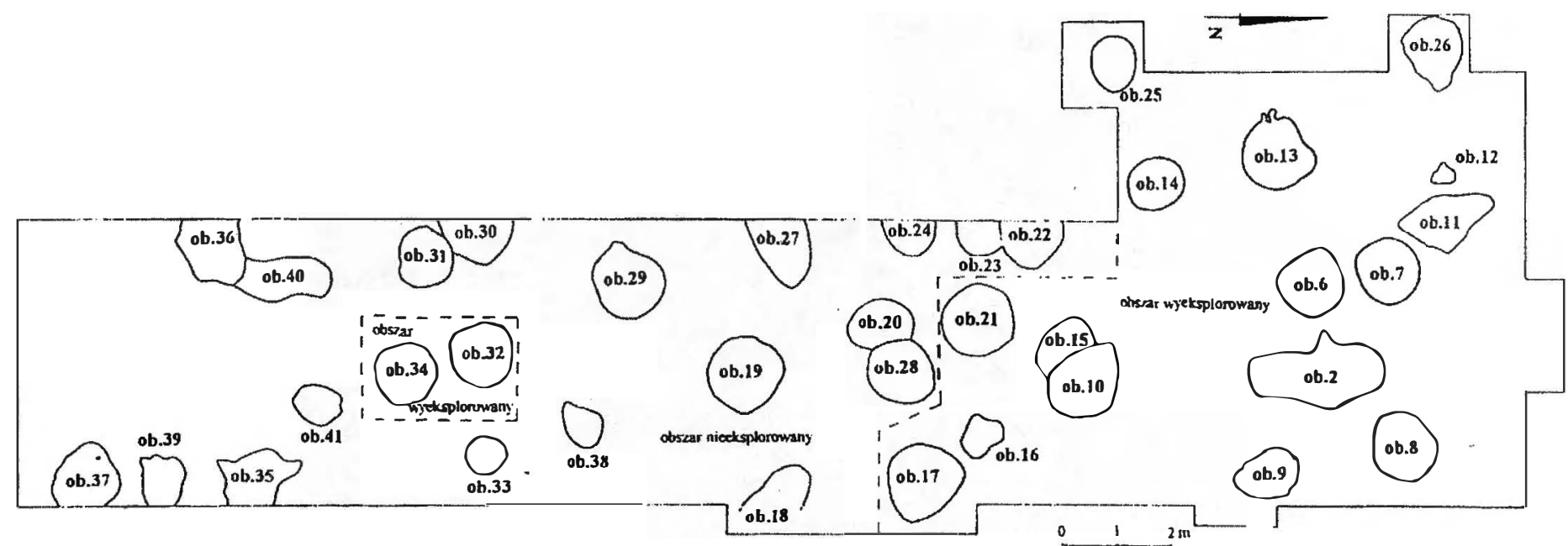




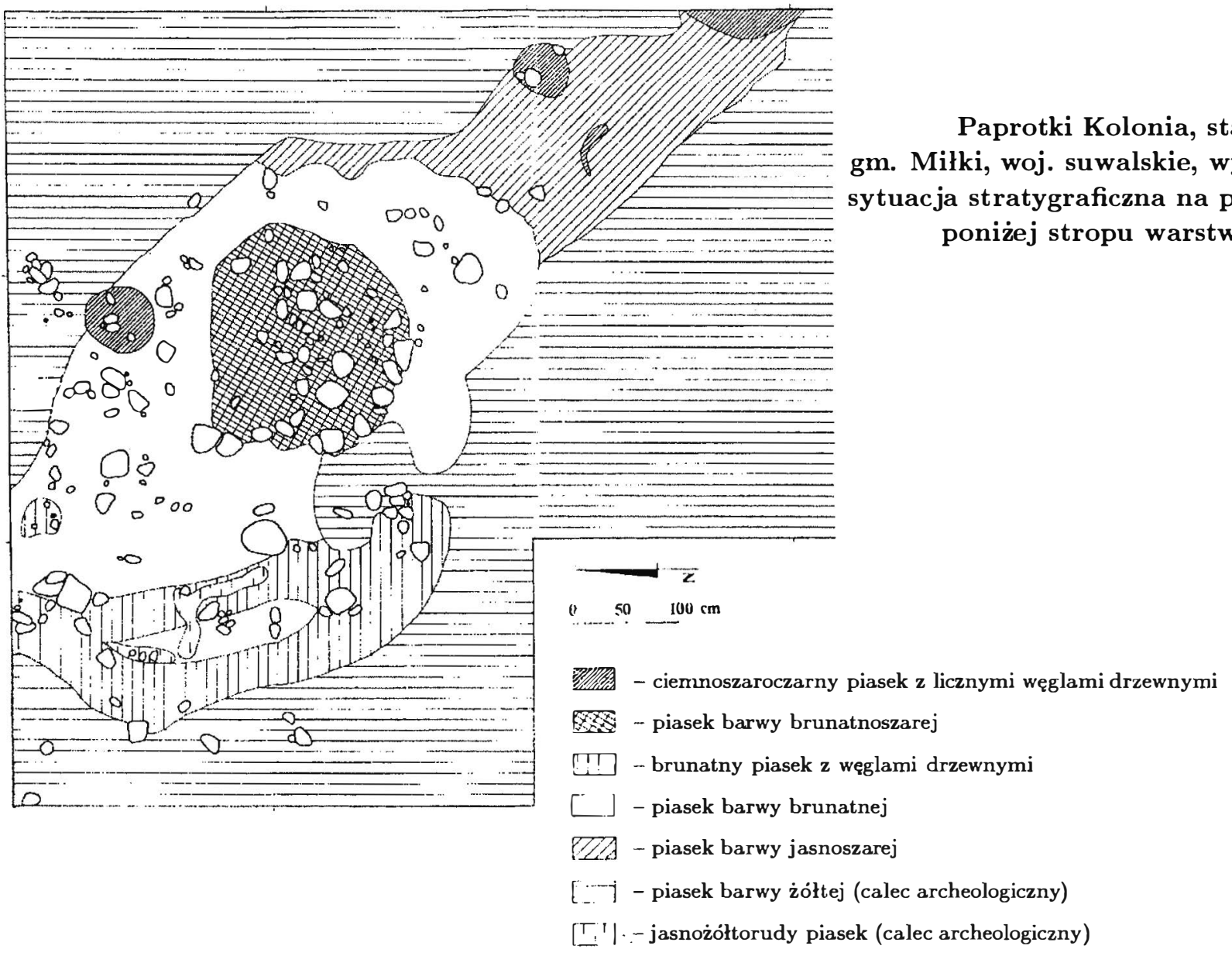

